\title{
Metode terapeutice adecvate în schimbarea comportamentului homosexual
}

\author{
Ilie Cristian MANTA*
}

Abstract: Adequate therapeutic methods in changing

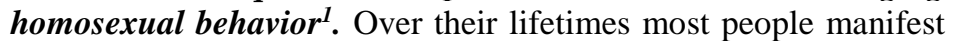
stability regarding their atraction, orientation and sexual identity, while a minority fluctuates. Sexual fluidity is more noticeable among gay and lesbian people. Some of the people who have followed sexual reorientation therapy have made some progress in their transition to heterosexuality. Posibile harms subsequent to such a therapy are not higher than those subsequent to therapies for various maladies. The present study aims to provide an overview of sexual reorientation therapy and other aspects that accompany it.

Keywords: sexual orientation, homosexuality, plasticity, convertion therapy, changed efforts, religiously mativated.

\section{Plasticitatea sexualității şi posibilitatea schimbării orientării sexuale}

Referindu-se la schimbarea orientării sexuale, la tranziția de la o orientare sexuală la alta, literatura de specialitate folosește termenul de fluiditate sexuală. În prezentarea de față, în locul termenului de fluiditate sexuală îl vom folosi pe cel de

* Doctorand în Teologie al Facultăţii de Teologie Ortodoxă „Sfântul Andrei Şaguna”, Universitatea „Lucian Blaga” din Sibiu, România.

${ }^{1}$ Studiu redactat sub îndrumarea Prof. Univ. Dr. Sebastian Moldovan, care şi-a exprimat acordul pentru publicare. 
plasticitate $^{2}$, preferându-1 pe acesta, deoarece plasticitatea exprimă mai bine poziția noastră teologică cu privire la structura ontologică a existenței umane.

Chestiunea referitoare la plasticitatea orientării sexuale și posibilitatea schimbării acesteia este una aprig discutată la nivelul comunității științifice, neajungându-se până în prezent la un punct de vedere care să întrunească consensul.

Astfel putem observa existența a două viziuni diametral opuse. Pe de o parte, avem punctul de vedere potrivit căruia orientarea sexuală este una fixă și, prin urmare, nu poate fi nicidecum schimbată, susținut de Asociația Americană de Psihiatrie (APA), Asociația Americană de Psihologie, de mare parte din susţinătorii drepturilor homosexualilor, de cercetători și reprezentanți ai organizațiilor din domeniul sănătăţii mintale. Pe de altă parte, avem vocea unei părți a comunității știinţifice, a diferitelor misiuni creștine specializate pe acordarea de sprijin celor cu atracții sexuale nedorite față de persoanele de același sex și vocea foștilor homosexuali, care susțin răspicat că orientarea sexuală este una fluidă și că ei sunt dovada vie că tranziția la heterosexualitate este cu adevărat posibilă.

${ }^{2}$ În timp ce fluiditatea ne arată că fluidul nu are nicio formă, ci ia forma vasului în care este pus, plasticitatea indică faptul că un anume obiect poate fi tare, dar cu toate acestea, are și o anume plasticitate. Plastilina are o formă, însă aceasta este una maleabilă. Ea nu își adaptează forma în funcție de vasul în care este pusă. Identitatea sexuală nu este atât de plastică încât să poți face din ea orice, unii rămânând mutilați dacă optează pentru schimbarea ei. Un caz elocvent în această privință este cel al lui Brian Reimer, un băiețel căruia la 8 luni, în urma unei operații de circumcizie, i-a fost lezat penisul și a rămas mutilat. Doctorul John Money, psihiatru american la spitalul John Hopkins din Baltimore, le propune părinților o operație de schimbare a sexului. Aceasta se realizează, iar băiețelul primește numele de Brenda și este crescut asemenea unei fetițe. Reimer a suferit foarte mult în urma acestor schimbări la care a fost supus, fiind chinuit și de ideea sinuciderii. La 13 ani află adevărul în legătură cu experiența suferită și decide să redevină băiat. Se redenumise David, s-a și căsătorit, însă la vârsta de 38 ani și-a pus capăt zilelor. Fratele său geamăn pe nume Bruce murise înainte cu doi ani, în urma unei supradoze de medicamente. (Vezi: Secretele Istoriei, Cazul David Reimer, un experiment psihologic care a șocat, disponibil la: https://cultural.bzi.ro/cazul-david-reimer-un-experiment-psihologic-care-a-socat17401 (accesat la data de 8.11.2017). Termenul de fluiditate va fi întrebuințat doar acolo unde îl folosesc autorii citați. 
Potrivit lui Eleonor Whiteway şi Denis Alexander, care fac referire la cercetări de lungă durată din Statele Unite ale Americii și Noua Zeelandă ${ }^{3}$, o majoritate covârșitoare a indivizilor (între 80$90 \%$ ), prezintă atracții sexuale și o identitate sexuală stabilă de-a lungul vieții. Există și „o minoritate sesizabilă” care experimentează schimbări de-a lungul timpului"4, schimbări care au loc în ambele direcții: atât de la homosexualitate la heterosexualitate, cât și în sens invers.

Studiind caracteristicile dezvoltării sexuale în rândul tinerilor și adolescenților, cercetătorii Savin-Williams și Ream au ajuns la concluzia că $75 \%$ dintre adolescenții care în perioada 17 21 ani au manifestat un anumit interes față de persoanele de același sex au dezvoltat ca adulți atracții exclusiv heterosexuale, în timp ce 98\% dintre adolescenții cu atracții față de sexul opus au rămas heterosexuali și ca adulți ${ }^{5}$. De asemenea, studiul lui Katz-Wise și Hide din anul 2015 indică faptul că, dintre persoanele care manifestă atracții față de același sex, 63\% dintre femei şi 50\% dintre bărbaţii cu vârsta între 18 şi 26 de ani, îşi schimbaseră atracţia cel puţin o dată, iar aproximativ $20 \%$ au avut schimbări multiple, prima petrecându-se la sfârşitul adolescenţei ${ }^{6}$. Lisa

3 Steven E. Mock, Richard P. EIBACH, „Stability and change in sexual orientation identity over a 10-year period in adulthood", în Archives of Sexual Behavior, Vol. 41, 3/2012, p. 641-648; Miles Q. OTт, Heather L. Corliss, David WypiJ, Margaret Rosario, S. Bryn Austin, „Stability and change in self-reported sexual orientation identity in young people: Application of mobility metrics", în Archives of Sexual Behavior, Vol. 40, 3/2011, p. 519-532.

${ }^{4}$ Eleonor Whiteway, Denis R. AleXANDER, „Understanding the causes of samesex attraction", în Science \& Christian Belief, Vol. 27, 1/2015, p. 17-40.

${ }^{5}$ Ritch C. SAVIN-Williams, Geoffrey L. REAM, „Prevalence and stability of sexual orientation components during adolescence and young adulthood", în Archives of Sexual Behaviour, Vol. 36, 2007, p. 385-394, apud Neil. E WHITEHEAD, Briar WHITEHEAD, Se poate schimba orientarea sexuală, disponibil la https://contracurentului.com/se-poate-schimba-orientareasexuala/ (accesat la data de 27.01.2018).

${ }^{6}$ Sabra L. KATZ-Wise, Janet S. HydE, „Sexual Fluidity and Related Attitudes and Beliefs among Young Adults with a Same-Gender Orientation", în Archives of Sexual Behavior, Vol. 44, 2015, p. 1459-1470. 
Diamond $^{7}$, în prezent cea mai cunoscută cercetătoare în privința plasticității sexuale, susține că eșantioane reprezentative de adolescenți și adulți, realizate de corpul științific internațional actual, arată că orientarea sexuală nu este ,o trăsătură statică și categorică" ${ }^{\prime}$, confirmând faptul că ,,sexualitatea de tip homosexual prezintă o fluiditate substanțială atât la bărbați, cât și la femei, iar această fluiditate ia o serie de forme" .

Datele de mai sus sunt în mare parte confirmate de Lawrence Mayer şi Paul McHugh, doi clinicieni şi oameni de știință distinși, care fac referire la studii longitudinale ${ }^{10}$ realizate în rândul adolescenților și din care reiese faptul că ,pentru unii oameni, orientarea sexuală poate fi destul de fluidă în cursul vieții.... 80\% dintre adolescenții de sex masculin care au raportat atracții homosexuale nu mai fac acest lucru ca adulți" "11. De asemenea, Laumann și colaboratorii săi, făcând referire la felul în care

${ }^{7}$ Lisa Diamond este psiholog si cercetător american, profesoară la Universitatea din Utah. Este cunoscută mai ales prin lucrarea Sexual Fluidity: Understanding Women's Love and Desire apărută în 2009, în care tratează despre plasticitatea sexualității feminine plecând de la un studiu în care a examinat parcursul a o sută de femei non-heterosexuale de-a lungul a 10 ani.

${ }^{8}$ Lisa M. Diamond, „Sexual Fluidity in Male and Females”, în Current Sexual Health Reports, 8/ 2016, p. 249-256.

${ }^{9}$ Ibidem.

${ }^{10}$ Referindu-se la calitatea studiilor de cercetare care urmăresc schimbarea orientării sexuale mediate religios, Stanton Jones spunea că un astfel de studiu trebuie să fie longitudinal (urmărirea subiecților să aibă loc pe o perioadă semnificativă de timp), să fie prospectiv (din punct de vedere al constatării diferitelor aspecte privind schimbarea orientării sexuale, intervenția în procesul schimbării să aibă loc cât de timpuriu posibil și astfel să fie urmărită evoluția persoanele în timp) și să folosească măsuri standardizate (întrebări standardizate și cele mai bune instrumente de sondaj în ce privește orientarea sexuală şi vătămarea). Doar în acest fel, un astfel de studiu poate prezenta credibilitate pentru comunitatea științifică, rezultatele obținute putând fi compatibile cu a altor studii din această zonă de cercetare. (Vezi Stanton L. Jones, Ex-Gays? Part 1: Research Design, disponibil la https://www.youtube.com/watch?v= I10jcafnqfe (accesat la 7.07.2020).

${ }^{11}$ Lawrence S. MAYeR, Paul R. MCHUGH, „Sexuality and Gender: Findings from the Biological, Psychological, and Social Sciences", în New Atlantis, 50/2016, p. 7 . 
orientarea homosexuală se dezvoltă și evoluează de-a lungul vieții, au constatat că aceasta nu este o, ,caracteristică stabilă” tinzând, ,să se transforme spontan în heterosexualitate pe măsură ce individul îmbătrâneşte"12, lucru valabil atât la bărbaţi, cât şi la femei.

Prin urmare, se constată faptul că există o oarecare maleabilitate, plasticitate a sexualității, dar nu chiar fluiditate. Este adevărat că trebuie să manifestăm prudență cu ceea ce înseamnă această plasticitate deoarece ea poate fi valorificată ideologic și în alte direcții. Cel puțin o parte a cercetării arată faptul că există o largă majoritate în rândul persoanelor care de-a lungul vieții manifestă stabilitate în ceea ce privește identitatea, atracția și orientare sexuală, că doar o minoritate prezintă fluctuații ale acestora și de asemenea că, plasticitatea sexuală este mai mare în rândul persoanelor gay și a lesbienelor.

Stabilitatea identităţii, atracției şi orientării sexuale a majorității persoanelor umane este un aspect confirmat de Revelația dumnezeiască. Sfânta Scriptură relatează încă din primele ei pagini faptul că Dumnezeu 1-a creat pe om parte

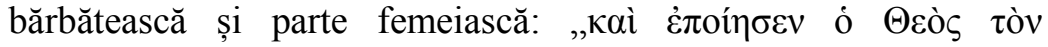

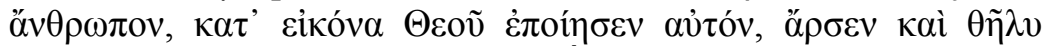

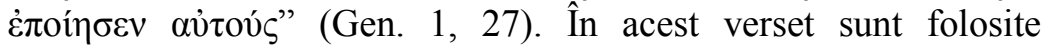

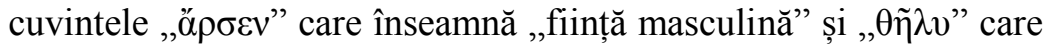
se traduce prin ,ființă feminină”, fapt ce arată că Dumnezeu a creat de la începutul omenirii două ființe de genuri diferite, cu particularități diferite, chemate la complementaritate: „De aceea va lăsa omul pe tatăl său și pe mama sa și se va lipi de femeia sa și vor fi amândoi un trup" (Gen. 2, 24).

Pe de altă parte, structură ontologică a existenței umane a suferit modificări în urma căderii în păcat a protopărinților și este

12 Edward O. Laumann, John N. Gagnon, Robert T. Michael, Stuart Michaels, The Social Organization of Sexuality. Sexual Practices in the United States, Chicago, Illinois, University of Chicago Press, 1994, apud Jeffrey B. SATIOVER, The "Trojan Couch": How the Mental Health Associations Misrepresent Science, disponibil la: https://pdfs.semanticscholar.org /8ba2/e0abf9e8d921bbb2447eab90f8b47c52ab1b.pdf?_ga=2.77721748.16513 72620.1567087942-600799073.1567087942 (accesat la data de 14.07.2020). 
afectată în continuare atât de păcatele părinților, cât și de cele personale şi de păcatele societății în ansamblul ei. Cu toate că a fost desfigurată, ea nu se schimbă cu totul. Și în cazul sexualității, fiecare primim prin creație anumite caracteristici stabile care ne definesc ca bărbat și femeie (cu excepția cazurilor patologice, desigur). Păcatul originar însă, a produs stricăciune și în privința sexualității. Prin cădere, ceea ce înseamnă bărbat și femeie nu a dispărut ca atare, dar așa cum toate lucrurile sunt afectate de mortalitate, de stricăciune și lupta de supraviețuire, este de așteptat ca și identitatea sexuală a protopărinților să fi suferit în urma căderii și să fi suportat urmări negative în modul de manifestare și înțelegere a sexualităţii. Prevederile vechi-testamentare referitoare la homosexualitate (Levitic 18, 22; 20, 13), zoofilie etc., porunca din Decalog care interzice adulterul (Ieş. 20, 14), sunt indicii care arată că, în condițiile căderii în păcat a omului și a pierderii de către acesta a stării paradisiace, Dumnezeu intervine cu reglementări precise și în ceea ce privește sexualitatea și manifestarea acesteia pentru a ține lucrurile sub control.

\section{Eforturile de schimbare a orientării sexuale}

Intr-un articol precedent ${ }^{13}$ am arătat faptul că la nivelul comunității științifice este recunoscut faptul că nu putem vorbi de un determinism preponderent genetic în ceea ce privește atracția față de persoanele de același sex, că nu există o genă gay ${ }^{14}$ și chiar dacă putem vorbi de o componentă genetică în privința

13 Ilie Cristian MANTA, „Rolul eredității și al educației în apariția și dezvoltarea comportamentului homosexual", în Altarul Reîntregirii, No. 1, ianuarieaprilie, 2019, p. 117-134; disponibil și la http://fto.ro/altarul-reintregirii/wpcontent/uploads/2020/05/12.-Ilie-Cristian-MANTA-AR1-2019.pdf (accesat la data de 21.07.2020).

14 Andrea GANNA et alli, „Large-scale GWAS reveals insights into the genetic architecture of same-sex sexual behavior", în Science, Vol. 365, No. 6456, 2019, disponibil la https://geneticsexbehavior.info/wp-content/uploads/ 2019/08/ganna190830. pdf (accesat la data de 28.09.2019). 
preferințelor sexuale ,nicio genă nu are efect major asupra componentelor sexuale" $"$.

Or, dacă ereditatea nu joacă un rol decisiv în determinarea atracției, orientării și comportamentului homosexual, dacă în stabilirea orientării sexuale factorul biologic (gene, hormoni etc.) nu este singurul răspunzător existând o serie de alte influențe ce țin de educație și diverşi factori de mediu, atunci acest lucru arată că „terapia în zona de orientare sexuală este o opțiune posibilă. O astfel de terapie nu va întâlni bariere ale structurii cerebrale deja formate în uter imposibil de trecut și care sunt desigur inalterabile" $" 16$.

Referind-se la capacitatea de schimbare la nivel uman în general, Graham Music confirmă faptul că schimbarea este posibilă pe durata întregii vieți. El amintește de ajutorul acordat prin intermediul psihoterapiei care ,dă naștere unor schimbări evidente la nivelul creierului, mai ales pentru acele zone care au legătură cu reglementarea emoțională, introspecția, memoria și autoreflecția"17. Potrivit lui Graham Music, acest lucru este posibil datorită faptului că alături de experiențe, modele comportamentale și circuite bine sedimentate la nivelul organismului uman, prin intermediul unor experiențe noi ,se pot forma și dezvolta noi circuite, noi țesuturi nervoase în anumite zone cerebrale"18. El vorbește despre „ferestre de oportunitate” care se ivesc mai ales în ultimul trimestru de sarcină și primii ani de viață, dar și în adolescență, în timpul cărora se produc anumite aspecte ale dezvoltării cerebrale.

Eforturile de schimbarea a orientării sexuale prin intermediul mijloacelor terapeutice s-au concentrat în ceea ce numim astăzi

15 Jonathan LAMBERT, No 'gay gene': Massive study homes in on genetic basis of human sexuality, disponibil la https:/www.nature.com/articles/d41586-01902585-6 (accesat la data de 25.09.2019).

16 Neil WhITEHEAD, ,Prenatal hormones are only a minor contributor to male brain structure in humans", în Journal of Human Sexuality, Vol. 6, 2014, p. 104-126.

17 Graham Music, Nurturing Natures. Attachment and Children's Emotional, Sociocultural and Brain Development, Second Edition, New York, Routledge, Taylor \& Francis Group, 2007, p. 104.

${ }^{18}$ Ibidem, p. 103. 
terapie de conversie, terapie reparatorie sau terapie pentru reorientare sexuală. Discuțiile actuale referitoare la eforturile de schimbare a orientării sexuale se reduc mai ales la două aspecte și anume: dacă aceste terapii sunt cu adevărat eficiente și dacă sunt ele dăunătoare sau nu.

Asociația Americană de Psihiatrie (APA) prin declarația din 1998 a precizat că ,se opune oricărui tratament psihiatric, cum ar fi terapia «reparativă» sau «de conversie», care se bazează pe presupunerea că homosexualitatea este în sine o tulburare mintală sau se bazează pe presupunerea a priori că pacientul ar trebui să-și schimbe orientarea homosexuală" 19 . APA a dezvoltat această poziție în anul 2013 afirmând:

\begin{abstract}
„Asociația Americană de Psihiatrie nu crede că orientarea între persoane de același sex ar trebui sau trebuie schimbată, iar eforturile de a face acest lucru reprezintă un risc semnificativ de vătămare prin supunerea persoanelor la forme de tratament care nu au fost validate științific și prin subminarea respectului de sine atunci când orientarea sexuală eșuează la schimbare. Nu există dovezi credibile potrivit cărora orice intervenție de sănătate mintală poate schimba în mod real și sigur orientarea sexuală" ${ }^{20}$.
\end{abstract}

Unul din studiile pe care se sprijină această viziune este cel realizat în anul 2002 de Shidlo și Schroeder ${ }^{21}$, doi psihologi din New York, studiu din care reiese că din cei 215 de subiecți homosexuali care au primit terapie pentru a-și schimba orientarea sexuală, majoritatea au eșuat în acest demers ${ }^{22}$. Studiul celor doi autori a

19 American Psychiatric Association, APA Reiterates Strong Opposition to Conversion Therapy, disponibil la https://www. psychiatry.org/ newsroom/news-releases/apa-reiterates-strong-opposition-to-conversiontherapy (accesat la data de 8.07.2020).

${ }^{20}$ Ibidem.

${ }^{21}$ Ariel SHIDLO, Michael SCHROEDER, „Changing sexual orientation: A consumers' report", în Professional Psychology: Research and Practice, Vol. 33, 3/ 2002, p. 249-259.

${ }^{22}$ Ibidem. 
întâmpinat mai mule critici ${ }^{23}$, însă dincolo de acest fapt, Shidlo și Schroeder au recunoscut că datele furnizate de ei „nu oferă informații privitoare la incidența și prevalența eșecului, succesului, vătămării, ajutorului sau încălcărilor etice în terapia de conversie. Datele calitative obținute pot servi la dezvoltarea de măsuri cantitative riguroase care trebuie validate în studiile viitoare" 24 .

Punctul de vedere emis de Asociația Americană de Psihiatrie este împărtășit și de Asociația Americană de Psihologie, concluzia acesteia fiind că ,...nu există dovezi suficiente pentru a susţine utilizarea intervențiilor psihologice pentru a schimba orientarea sexuală." 25

În Regatul Unit, 17 organizații au semnat în anul 2017 un protocol de acord ${ }^{26}$ referitor la terapia de conversie, în care este stipulat faptul că ,eforturile de a încerca să schimbi sau să modifici orientarea sexuală prin terapii psihologice sunt contrare eticii și potențial vătămătoare" 27 .

Dintre practicienii terapiei de conversie îi amintesc aici pe Irving Beiber, Charles W. Socarides, Joseph Nicolosi, Albert Dean Byrd, însă abordările lor au fost adesea criticate. De exemplu, psihologul Douglas Haldeman susține că aceste terapii sunt neetice deoarece ,se bazează pe o devalorizare a identităţii homosexuale și a comportamentului" ${ }^{28}$, în timp ce Gerald Davison

${ }^{23}$ Dermot O'CAllaghan, New Study: Effects of Therapy on Religious Men who have Unwanted Same-Sex Attraction, disponibil la https://www.coreissues.org/leading-stories-and-research/new-study-effects-of-therapy-on-religious -men-who-have-unwanted-same-sex-attraction (accesat la data de 20.10.2019).

${ }^{24}$ Ibidem.

25 American Psychological Association, Resolution on Appropriate Afirmative Responses to Sexual Orientation Destress and Change Efforts, disponibil la https:// www.apa.org/about/policy/sexual-orientation (accesat la data de 8.07.2020).

${ }^{26}$ Dintre semnatarii acestui acord fac parte Asociația Consilierilor Creștini, şapte grupări profesionale preocupate de consiliere/psihoterapie, două Colegii Regale și Serviciul Național de Sănătate (NHS) din Anglia și Scoția.

27 Christopher C. H. CooK, „Science and theology in human sexuality”, în Theology \& Sexuality, Vol. 24, 3/2018, p. 183-199.

28 Douglas C. HALDEMAN, „The practice and ethics of sexual orientation conversion therapy", în Journal of Consulting and Clinical Psychology, Vol. $62,2 / 1994$, p. 221-227. 
militează pentru interzicerea acestora, deoarece existența lor este dovada „prejudecăţilor profesionale și sociale” la adresa homosexualitătii, neexistând date care să demonstreze că terapiile reparatorii sunt eficiente ${ }^{29}$.

Fără a nega pertinența unora dintre critici la adresa diferitelor forme de terapie, autorii lor tind totuşi să neglijeze nu doar cercetările anterioare anului 1973 care vorbesc de succesul terapiei, ci și rezultatele pozitive ale unor cercetări recente, bine documentate și realizate după o metodologie conformă standardelor științifice. Se poate spune, fără să greșim, că cel mai cunoscut studiu în ceea ce privește terapia de conversie este cel al cercetătorului Robert L. Spitzer ${ }^{30}$, psihiatru și cercetător eminent, un susţinător îndelungat al drepturilor homosexualilor, considerat „arhitectul” deciziei Asociației Americane de Psihiatrie din anul 1973, decizie în urma căreia homosexualitatea a fost eliminată ca și categorie de diagnostic din a doua ediție a Manualului de Diagnoză și Statistică al Tulburărilor Mintale, (The Diagnostic and Statistical Manual of Mental Disorders/DSM-II), aceasta nemaifiind socotită o tulburare mintală.

Studiul lui Spritzer este cunoscut atât de cei ce se împotrivesc terapiei de conversie, cât și de cei ce pledează pentru acest gen de terapie, și aceasta deoarece, în jurul acestui studiu, sau iscat multe discuții care au fost vizibile nu doar în interiorul comunității științifice, ci şi în mass-media.

Spitzer a chestionat 200 de persoane (143 bărbaţi și 57 femei), toți fiind atrași sexual de persoane de același sex înainte de a urma o anumită formă a terapiei de conversie. Majoritatea

29 Gerald C. DAvison, „Politics, ethics and therapy for homosexuality”, în J. GONSIOREK, Homosexuality and psychotherapy, NY Haworth Press, 1982, p. 89-96, apud Dale O'LeARY, Dean BYRD, Richard P. FitzGibBons, James E. PhElAn, The Same-Sex Attraction Factsheet, disponibil la http://www.familieslink.co.uk/download/sept07/same\%20sex\%20alleged\% 20fact\%20sheet. pdf (accesat la data de 28.04.2018).

30 Robert L. SPITZER, „Can some gay men and lesbians change their sexual orientation? 200 participants reporting a change from homosexual to heterosexual orientation", în Archives of Sexual Behavior, Vol. 32, 5, 2003, p. 403-417. 
participanților aveau o implicare religioasă superioară decât media populației, 93\% dintre ei declarând că religia este „extrem” sau „foarte" importantă în viaţa lor. Conform spuselor lui Spitzer, terapia a funcționat cel puțin în cazul indivizilor foarte motivați și a concluzionat că ,există dovezi că, urmând o anumită formă de terapie reparatorie, se produce schimbarea în ceea ce privește orientarea sexuală în cazul unor homosexuali și lesbiene" Potrivit cuvintelor unui coleg gay de-al său, constatarea lui Spitzer a fost asemenea unei ,grenade aruncate în comunitatea gay" 32 , înfuriind susținătorii drepturilor homosexualilor.

Ulterior Spitzer și-a cerut iertare atât comunității gay pentru faptul că în studiul său ar fi făcut afirmații neprobate despre eficiența terapiei reparatorii, cât și persoanelor gay care au urmat o anumită formă de terapie reparatorie doar pentru că el ar fi dovedit că aceasta ar da rezultate în cazul indivizilor foarte bine motivați, irosindu-și astfel timpul și energia.

De asemenea, Spitzer i-a cerut lui Kenneth Zucher, editorul publicaței Archives of Sexual Behavior, retragerea studiului, însă acesta a refuzat. Iată cum și-a motivat Zucher refuzul: „Putetţi retrage datele incorect analizate; pentru aceasta publicați un erratum. Puteți retrage un articol dacă datele au fost falsificate sau îl retrage revista dacă editorul are cunoștință de acest fapt. Dacă înțeleg bine, el (Spitzer) spune după 10 ani că vrea să retragă interpretarea datelor. Ei bine, în materie de interpretare, probabil că ar trebui să retragem sute de studii știinţifice și noi nu facem acest lucru"33.

${ }^{31}$ Ibidem.

${ }^{32}$ Gabriel Arana, My So-Called Ex-Gay Life. A deep look at the fringe movement that just lost its only shred of scientific support, disponibil la https://prospect.org/civil-rights/so-called-ex-gay-life/ (accesat la data de 17.07.2020).

33 Alice Dreger, How to ex an "ex-gay" study. A small but critical correction on a new, very moving article, Web log post retrieved from http://psychologytoday.com/blog/fetishes-i-dont-get/201204/how-ex-ex-gaystudy (accesat la data de 7.07.2020), apud Christopher H. RosIK, „A research review of 'Parent-initiated sexual orientation change efforts with LGBT adolescents: mplications for young adult mental health and 
În anul 2012, Spitzer a realizat o reevaluare ${ }^{34}$ a studiului său publicat în anul 2003, însă chiar dacă se poate spune că Spitzer și-a retras interpretarea personală a datelor, rezultatele, așa cum au fost ele prezentate, rămân valabile. Prin urmare, fiecare e lăsat să aleagă una din variante și anume „fie că participanții la studiul lui Spitzer au mințit ori s-au înșelat, fie că o parte sau chiar mulți dintre ei au raportat propria experiență reală de schimbare" ${ }^{\prime 3}$.

Douglas Haldeman a adus critici studiului lui Spitzer afirmând că experiențele descrise de subiecții lui ar trebui luate cu foarte mare rezervă, participanții nefiind suficient de credibili, aceștia fiind recomandați de grupuri religioase (43\%) și de Asociația de Cercetare și Terapie a Homosexualității (23\%), organizații care condamnă homosexualitatea și o consideră o tulburare de dezvoltare. Bineînțeles că afirmațiile lui Haldeman nu se justifică, întrucât, chiar dacă participanții au prezentat o religiozitate mai mare decât media populației, nu înseamnă nici că „experiențele lor trebuie respinse” nici că aceștia „nu spun adevărul.”36

Cercetările ulterioare referitoare la terapia mediată religios tind să confirme concluzia la care a ajuns Spitzer în urma studiul din 2003. Amintesc în acest sens studiul realizat de Santero, Whitehead și Ballestero ${ }^{37}$ la care au participat 125 de bărbați cu convingeri religioase ${ }^{38}$. Rezultatele acestui studiu au arătat că

adjustment' by Ryan et alli.", în Journal o Human Sexuality, Vol. 10, 2019, p. 80.

34 Robert L. SPITZER, „Spitzer reassesses his 2003 study of reparative therapy of homosexuality", în Archives of Sexual Behavior, Vol. 41, 4/2012, p. 757.

35 Jerry A. Armelli, Elton L. Moose, Anne PAulK, James E. Phelan, „A response to Spitzer's (2012) reassessment of his 2003 study of reparative therapy of homosexuality", în Archives of Sexual Behavior, Vol. 41, 6/2012, p. 1335-1336, apud Christopher H. RosiK, art. cit., p. 80.

36 Sarah AdLer, Edmund Levin, Some Gays Can Go Straight, Study Says, disponibil la https://abcnews.go.com/ Health/Sex/story?id=117465\&page=1 (accesat la data de 15.07.2020).

37 Paul L. SAntero, Neil E. Whitehead, Dolores Ballesteros, „Effects of Therapy on Religious Men Who have Unwanted Same-Sex Attraction", în The Linacre Quarterly, 23 iulie 2018, p. 1-17.

${ }^{38}$ Alte date ale studiului indică faptul că din cei 125 de bărbați care au luat parte la studiu, $89 \%$ au fost creștini de tradiții diferite: $13,6 \%$ creștini fără 
$68 \%$ dintre participanți au raportat o reducere semnificativă - „de la ceva la mult" - a atracției față de acelaşi sex şi a comportamentului homosexual și o creștere a atracției față de sexul opus și comportamentul heterosexual. Într-un articol din 2019 apărut în Journal of Human Sexuality, referindu-se la studiul publicat în 2018, Whitehead spunea că în opoziție cu raportul Task Force ${ }^{39}$ al Asociației Americane de Psihologie, rezultatele înregistrate în urma terapiei arată că ,există o schimbare reală, puțină vătămare, mult bine, rezultatele fiind foarte asemănătoare cu cele din cercetarea lui Jones si Yarhouse din anul 2011"40. Studiul lui Jones si Yarhouse ${ }^{4142}$ a început cu 98 de participanți (72 bărbați si 26 femei) și s-a încheiat cu 65. Dintre cei care au renunțat, unii și-au motivat decizia prin faptul că s-au vindecat de homosexualitate, iar alții au afirmat că sunt gay și au încetat să încerce să se schimbe. În ceea ce privește

apartenență confesională, 5\% romano-catolici, $28 \%$ mormoni, 9,6\% evrei, $0,8 \%$ bahai și $0 \%$ agnostici sau atei; $55 \%$ au afirmat că participă săptămânal la serviciile religioase; $54 \%$ erau celibatari, $46 \%$ erau căsătoriți și $42 \%$ aveau copii, iar numărul de homosexuali activi era aproximativ egal cu al homosexualilor abstinenți. La data efectuării studiului $42 \%$ urmau programul de terapie, iar 58\% îl finalizaseră.

39 American Psychological Association (APA), Report of the American Psychological Association Task Force on Appropriate Therapeutic Responses to Sexual Orientation, Washington, D.C., 2009, disponibil la https://www.apa.org/pi/lgbt/resources/therapeutic-response.pdf (accesat la data de 18.07.2020).

40 Neil E. WhiteheAD, „Publication and Retraction of the Santero, Whitehead, Ballesteros (2018) Study: A First-Hand Account", în Journal of Human Sexuality, Vol. 10, 2019, p. 75.

41 Stanton L. Jones, Mark A. YARHouse, „A Longitudinal Study of Attempted Religiously Mediated Sexual Orientation Change", în Journal of Sex and Marital Therapy, Vol 37, 5/2011, p. 404-427.

${ }^{42}$ Rapoarte anterioare detaliate asupra studiului au fost publicate în anul 2017 în lucrarea: Ex-Gays? A Longitudinal Study of Religiously Mediated Change in Sexual Orientation (Downers Grove, III: InterVarsity Press, 2007) și prezentate convenției Asociației Americane de Psihologie în anul 2009 (vezi: Ex Gays? An Extended Longitudinal Study of Attempted Religiously Mediated Change in Sexual Orientation, Sexual Orientation and Faith Tradition Symposium, APA Convention, 2009). 
reuşita schimbării, din cei 98 de subiecți, mai mult de jumătate $(53 \%)$ au fost raportaţi drept cazuri de succes. Prin succes, autorii înțeleg atât „o reducere substanțială a atracției homosexuale și schimbare «conversion» substanțială spre atracția și funcționare heterosexuală" $(23 \%)^{43}$ cât și castitate «chastity», în acest caz subiecții raportând că ,atracția homosexuală este prezentă doar întâmplător şi într-un mod care nu pare a le produce suferinţă, permițându-le să trăiască mulțumiți, fără ca activitatea sexuală să se manifeste"44 (30\%). De asemenea, 20\% dintre subiecți au raportat renunțarea la lupta pentru schimbare, fiind înregistrate drept ,rezultate negative, opuse efectului de schimbare așteptat" $"$ ".

Solicitând prudență în interpretarea rezultatelor din studiul lor, Jones și Yarhouse susțin că acestea „,nu dovedesc că o schimbare categorică în privința orientării sexuale este posibilă pentru toată lumea și pentru oricine, ci, mai degrabă, că schimbări semnificative de-a lungul unui continuum (...) apar posibile pentru unii. Rezultatele nu dovedesc că nimeni nu este rănit prin încercarea de schimbare, ci mai degrabă că, în medie, încercarea (de schimbare) nu pare să fie dăunătoare sau inerent dăunătoare"46.

Prin urmare, se poate afirma, că deși nu se schimbă toți cei ce urmează terapia de conversie, o parte dintre cei implicați înregistrează un anumit grad de progres, iar în cazul celor foarte motivați, schimbarea spre heterosexualitate este una semnificativă. Dr. Dean Byrd ${ }^{47}$ spune că ,,unele persoane pot și chiar se schimbă.

${ }^{43}$ Stanton L. Jones, Mark A. YARHouse, „Ex Gays? An Extended Longitudinal Study of Attempted Religiously Mediated Change in Sexual Orientation", în Sexual Orientation and Faith Tradition Symposium, APA Convention, 2009, disponibil la https://www.wthrockmorton.com/wp-content/uploads/2009/ 08/Jones-and-Yarhouse-Final.pdf (accesat la data de 18.07.2020).

${ }^{44}$ Ibidem.

${ }^{45}$ Ibidem.

${ }^{46}$ Warren Throckmorton, The Jones and Yarhouse study: What does it mean?, disponibil la https://www. wthrockmorton.com/2011/10/27/ the-jones-andyarhouse-study-what-does-it-mean/ (accesat la data de 18.07.2020).

${ }^{47}$ Dean Byrd, psihoterapeut, profesor și autorul a peste 100 de articole şi cărţi despre sexualitatea umană. 
Asta nu înseamnă că trebuie forțate să se schimbe, ci înseamnă că au dreptul la această opțiune" ${ }^{48}$. Jeffrey Satinover, psihiatru și psihanalist american, identifică 4 categorii de persoane pe care le-a întâlnit în profesia sa de-a lungul anilor și anume: persoane care sau schimbat într-o oarecare măsură, dar nu s-au schimbat mult; persoane care s-au schimbat mult; persoane care nu s-au schimbat chiar dacă au vrut să se schimbe și persoane - care se considerau a fi gay sau lesbiene - care nu aveau niciun interes să se schimbe ${ }^{49}$. De asemenea, Nicolas Cummings ${ }^{50}$, psiholog, fost președinte al Asociației Americane de Psihologie afirmă ,că a avut de-a face cu zeci de mii de pacienți homosexuali și lesbiene și poate spune că a văzut nu doar unul sau doi, ci sute care s-au schimbat și au îmbrățișat heterosexualitatea având o viață foarte fericită" ${ }^{51}$.

În cadrul terapiei de conversie, alături de terapia mediată religios întâlnim o serie de alte abordări ale terapiei comportamentale care folosesc diferite tehnici precum sensibilizarea ascunsă, formarea asertivității, psihoterapia de grup, abordări aversive etc. ${ }^{52}$. Terapia de conversie mediată religios $^{53}$ este o

${ }^{48}$ Family Watch International, Understanding Same-Sex Attraction, disponibil la https://www.youtube.com/watch?v=jJhy zqdzpnM (accesat la data de 5.07.2018).

${ }^{49}$ Ibidem.

${ }^{50}$ Nicolas Cummings este co-autorul lucrării Distructive Trends in Mental Health: The Well-Intentioned Path to Harm, în care descrie felul în care APA a ignorant știința care susține că orientarea sexuală poate fi schimbată.

${ }^{51}$ Family Watch International, Understanding Same-Sex Attraction, disponibil la https://www.youtube.com/watch?v=jJhy zqdzpnM (accesat la data de 5.07.2018).

52 Acest tip de abordare terapeutică nu mai este întâlnit în zilele noastre, fiind criticat de oamenii de știință și de activiștii gay. În cadrul acestui fel de terapie, în timp ce vizionau imagini cu scene erotice între persoane de același sex, pacienții erau expuși la șocuri electrice sau li se administrau medicamente care să le provoace greață.

53 Unul din textele nou-testamentare care dă mărturie despre posibilitatea vindecării de homosexualitate și care poate constitui drept fundament pentru terapia de conversie mediată religios este și cel din Epistola 1 către Corinteni capitolul 6 versetele 9-11. După ce enumeră mai multe păcate care reprezintă piedici în dobândirea Împărăției lui Dumnezeu, păcate printre care

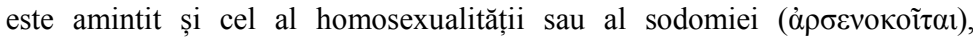


abordare religios-spirituală potrivit căreia schimbarea orientării homosexuale se poate realiza prin participarea la viața bisericii și printr-o îndrumare spirituală bazată pe convingeri creștine. Este o lucrare spirituală prin care, în urma unei lucrări teandrice, prin puterea și lucrarea Duhului Sfânt în inima omului și printr-o participare vie a persoanei umane la această lucrare, se produce o înnoire a vieții omului în Hristos și depășirea homosexualității apare ca posibilă. Luis Javier Ruiz, unul dintre participanții la Marșul Libertății care, în anul 2019 a avut loc în Washington D.C., a afirmat că „transformarea aceasta nu se referă la trecerea de la situaţia de persoană gay la situaţia de persoană hetero, ci de la situaţia de persoană pierdută la situația de persoană mântuită", exprimând prin aceasta că transformarea calitativă este mult mai mare ${ }^{54}$.

Dintre motivele care determină persoanele gay să facă pasul spre heterosexualitate, pe lângă descoperirea lui Dumnezeu și dorinţa de a trăi o viață nouă în Duhul Sfânt, departe de plăcerile vieții acesteia, aș mai enumera aici pe scurt visul, dorința unora de a se căsători, de a avea copii și o familie iubitoare, singurătatea odată cu înaintarea în vârstă, insecuritatea relațiilor homosexuale frământate adesea de infidelitate, conflicte interne, comportament compulsiv, gelozii, drame, ceea ce le fac să fie instabile și de scurtă durată etc. ${ }^{55}$. Foștii homosexuali identifică și două aspecte care, din punctul lor de vedere, sunt esenţiale în sprijinirea eforturilor de schimbare și anume: „o separare completă de stilul de viaţă homosexual (părăsirea relaţiei din prezent şi a mediului

Sfântul Apostol Pavel notează că unii s-au despovărat, s-au vindecat, de astfel de păcate: „Şi aşa eraţi unii dintre voi. Dar v-aţi spălat, dar v-aţi sfinţit, dar v-aţi îndreptat în numele Domnului Iisus Hristos şi în Duhul Dumnezeului nostru." (I Cor. 6, 11).

${ }^{54}$ Brandon SHOWALTER, Ex-LGBT men, women to share stories of transformation at 2nd Freedom March in Washington, D.C., disponibil la https://www.christianpost.com/news/ex-lgbt-men-women-to-share-storiesof-transformation-at-2nd-freedom-march-in-washington-dc.html (accesat la data de 25.05.2019), apud Ion Ciungu, Iisus în centrul cunoaşterii..., disponibil la: https://doisautreiinnumeleluiiisus.blogspot.com/2019/05/iisusin-centrul-cunoasteriiii-poate.html (accesat la data de 25.05.2019).

55 Voi reveni asupra acestui aspect într-o prezentare viitoare detaliată. 
homosexual, mutarea din zonă dacă este necesar) şi o reţea puternică de suport heterosexual, care să înlocuiască structura suportului homosexual"56.

În acest context în care am amintit de psihiatri, psihanaliști, terapeuți specialiști în terapia de conversie, de foști homosexuali care vorbesc despre rezultate certe în cazul celor ce isși doresc tranziția de la homosexualitate la heterosexualitate, amintesc poziția unui teolog care aparține tradiției răsăritene și care a zăbovit asupra diferitelor aspecte legate de homosexualitate și problematici LGBTIQ. Vasileios Thermos ${ }^{57}$, preot și medic psihiatru grec, într-un articol apărut în publicația The Wheel afirma următoarele în legătură cu terapia de conversie sau reparatorie: „Unele părți ale lumii protestante și-au pus, în mare parte, nădejdea, în terapiile de conversie și au organizat instituții care le oferă. După câteva decenii, ştim acum că eficiența lor este destul de limitată și adesea chiar dăunătoare psihologic" 58 . Iar în ce privește posibilitatea schimbării orientării sexuale și tranziția la heterosexualitate, pr. Thermos afirmă că: „căsătoria nu «vindecă» homosexualitatea; rugăciunea persistentă împreună cu o viață spirituală consecventă pot duce la virtute și sfințire, dar nu la o schimbare a orientării sexuale. Un astfel de sfat fals servește doar pentru a-1 scuti pe păstor de anxietatea lui, pentru că nu știe să rezolve în niciun alt mod această problemă spinoasă"59. Într-un viitor articol, pe baza mărturiei unor părinţi și teologi contemporani și a unor interviuri culese de la mai mulţi

56 Neil. E WhiteHEAD, Briar WhITEHEAD, Se poate schimba orientarea sexuală, disponibil la https://contracurentului. com/ se-poate-schimba-orientareasexuala/ (accesat la data de 27.01.2018).

57 Vasileios Thermos este preot ortodox aparținând Bisericii Ortodoxe a Greciei. A studiat medicina și teologia ortodoxă la Universitatea din Atena, unde deține și un doctorat. Alături de slujirea sacerdotală, pr. Thermos este profesor de teologie și psihologie pastorală la o școală cu profil teologic din Atena. De asemenea, este medic psihiatru, specializat în psihiatrie şi psihoterapie pentru copii și adolescenți. Este autor a mai multor cărți și articole, oferă consiliere spirituală și clinică, susținând mai multe conferințe în Grecia, SUA, Cipru, Albania, România.

58 Vasileios Thermos, „The Orthodox Church, Sexual Orientation, and Gender Identity: From Embarrassment to Vocation", în The Wheel, 13-14/2018, p. 86.

${ }^{59}$ Ibidem. 
duhovnici ortodocși, intenționez prezentarea unui punct de vedere asupra homosexualității și a posibilității depășirii atracțiilor și orientării față de persoanele de același sex, punct de vedere care să aparțină exclusiv tradiției răsăritene.

\section{Interzicerea terapiei de conversie în folosul cui?}

Și pe acest subiect poziționarea celor două tabere este perfect vizibilă și foarte bine delimitată, fiecare parte venind cu propriile argumente. Susținătorii drepturilor homosexualilor și activiștii gay folosesc drept argumente în sprijinul interzicerii terapiei faptul că homosexualitatea nu mai este considerată o tulburare mintală, că unele persoane se nasc gay și că orientarea sexuală nu este fluidă pentru a putea fi corectată prin terapie, că unele persoane recurg la terapie din pricina homofobiei manifestate la nivel social, precum și suportul științific care arată că terapia de conversie dăunează clienților. De cealaltă parte, pe lângă suportul științific care arată că schimbarea este posibilă cel puțin în cazul persoanelor bine motivate în acest sens, clinicienii și apărătorii terapiei de conversie aduc ca și argumente dreptul de alegere și „auto-determinare al clienților”, vocea foștilor homosexuali care dau mărturie despre propria schimbare și nu în ultimul rând ,respectul pentru diversitate"60.

Dincolo de argumentele celor două părți, datele indică faptul că lobby-ul LGBTIQ a exercitat presiuni la nivel politic, juridic, academic nu doar pentru obstrucționarea cercetării în legătură cu cauzele homosexualității ${ }^{61}$, ci că el s-a manifestat și în legătură cu interzicerea terapiei de conversie pe care o califică drept dăunătoare. Am observat faptul că, cel puțin o parte a cercetării raportează că terapia de conversie înregistrează rezultate pozitive, că schimbarea este posibilă cel puțin pentru unele persoane care sunt foarte

${ }^{60}$ Mark A. YARHOUSE, Warren THROCKMORTON, „Ethical issues in attempts to ban reorientation therapies", în Psychotherapy: Theory/Research/Practicel Training, Vol. 39, 1/2002, p. 66-75.

${ }^{61}$ Gabriele KuBy, Revoluția sexuală globală. Distrugerea libertății în numele libertății, Iași, Edit. Sapientia, 2014, p. 146. 
motivate în a se schimba și că riscul de vătămare nu este mai mare decât în cazul altor tipuri de terapii. În aceste condiții, ne putem întreba de ce terapia de conversie i-ar deranja foarte mult pe activiștii drepturilor homosexualilor și pe cei ce își afirmă deschis orientarea și identitatea gay. Dacă nimeni nu este forțat să urmeze diferite forme de terapie pentru schimbarea orientării sexuale, de unde atâta zel din partea activiștilor gay în interzicerea ei?

Existența în societate a ideii că persoanele homosexuale pot fi sprijinite în a face tranziția spre heterosexualitate reprezintă, potrivit lui Nicolosi, o , anatemă” pentru mișcarea LGBT și aceasta deoarece „lobby-ul LGBT nu suportă să vadă homosexualitatea tratată ca patologie și dorește să împiedice pe oricine caută să facă acest lucru, prin constrângere, dacă este necesar"62. Peter Sprigg ${ }^{63}$, cercetător în studii politice, afirmă că interdicțiile referitoarele la diversele programe care vizează eforturile de schimbare a orientării sexuale „nu se referă la terapie, ci la ideologie”. Adevărata problemă, potrivit lui Sprigg,

„,nu este că oamenii sunt răniţi de această terapie (nu sunt). Iar problema nu este că terapia nu reușește - Eu cred că activiștii LGBT sunt mai preocupaţi că terapia chiar reușește! Ceea ce îi preocupă este simpla existență în cadrul societăţii a persoanelor (fie terapeuți, clienți sau cetățeni obișnuiți) care consideră că a fi «gay» este un fapt de nedorit. Pentru aceasta vor să elimine credința oricui, că orice aspect al homosexualității (atracții, comportamente sau identitate) poate fi indezirabil" 64 .

62 Thomas D. Williams, Ex-Gays Fight LGBT Power Play to Outlaw Conversation Therapy, disponibil la http://www.pravmir.com/ williams-ex-gays-fight-lgbtpower-play-to-outlaw-conversion-therapy/ (accesat la data de 20.07.2020).

${ }^{63}$ Peter S. Sprigg este cercetător principal în studii politice la Familly Research Council din Washigton, D.C. Cercetarea și lucrările sale s-au axat pe probleme de căsătorie și familie, sexualitate umană, arte, divertisment și religia în viața publică. (vezi FRC Staff, Peter Sprigg-Senior Fellow for Policy Studies, disponibil la https://www.frc.org/get.cfm?i=by03f03 (accesat la data de 6.07.2020).

${ }^{64}$ Christopher H. RosiK, „Perspectives from the Front Lines of Therapy Ban Conflicts: An Interview with Peter Sprigg and Greg Burt", în Journal of Human sexuality, Vol. 10, 2019, p. 70. 
Referindu-se la eforturile de interzicere a terapiei de conversie, Joseph Nicolosi ${ }^{65}$ afirmă că aceste eforturi sunt larg răspândite și bine orchestrate provenind din interiorul comunității gay ai căror activiști se simt amenințați de reușitele acestei terapii. Pentru ei, mărturiile foștilor homosexuali despre propria schimbare reprezintă o adevărată amenințare la principiul de bază al agendei gay și anume acela de a-i face pe oameni să creadă că unele persoane se nasc pur si simplu homosexuali ${ }^{66}$. Nicolosi face referire la studii de sondare a opiniei publice care arată că dacă oamenii ajung să creadă că unii se nasc homosexuali, atunci „este foarte probabil ca lumea să accepte mult mai ușor homosexualitatea" $"$.

Conform Philadelpfia Gay News, până în anul 2013, două state din SUA, este vorba de New Jersey și California, ,au interzis practica terapeuților care se angajează în eforturile de schimbare a orientării sexuale pentru persoanele sub 18 ani" ${ }^{68}$. Amintesc de existența în California a proiectul de lege $A B-2943$ care a avut drept scop ,scoaterea în afara legii atât a distribuirii Bibliei, cât și oferirea de consiliere psihologică la cerere persoanelor care vor săși schimbe preferințele homosexuale" ${ }^{" 69}$. Tot în anul 2013, democratul Brian Sims, activist pentru drepturile civile ale membrilor comunității LGBT și primul legiuitor de stat ales din istoria statului Pennsylvania, declarat homosexual, lucra la un

65 Dr. Joseph Nicolosi este psiholog clinician licențiat şi administrează cea mai mare clinică de terapie reparatorie din lume.

${ }^{66}$ Family Watch International, Understanding Same-Sex Attraction, disponibil la https://www.youtube.com/watch? $\mathrm{v}=\mathrm{jJhy}$ zqdzpnM (accesat la data de 5.07.2018).

${ }^{67}$ Joseph NicOLOSI, Cauzele și tratarea homosexualității masculine, disponibil la https://www.youtube.com/watch?v=pkuMlypiChQ (accesat la data de 5.07.2017).

68 PGN Staff, Sims To Introduce Bill To Ban Consersion Therapy, September 19, 2013, disponibil la https://epgn.com/2013/09/19/23644231-sims-tointroduce-bill-to-ban-conversion-therapy/ (accesat la data de 17.07.2018).

69 Știri pentru Viață, Mărturiile unor foști homosexuali și lesbiene: ,, Sunt mai mult decât propria sexualitate", disponibil la https://stiripentruviata.ro/marturiileunor-fosti-homosexuali-si-lesbiene-sunt-mai-mult-decat-propria-sexualitate/ (accesat la data de 9.06.2018). 
proiect de lege asemănător care să fie introdus și în statul Pennsylvania ${ }^{70}$.

Unele state americane precum California, New Jersey, Illinois, Oregon, Vermont, Washington D.C., au scos în afara legii terapia de conversie pentru minori, iar altele precum Seattle, Cincinnati, Pittsburgh, au adoptat o legislație similară $\breve{71}^{71}$ astfel că în prezent, în SUA, sunt 14 state care au interzis terapia de conversie, Asociația Americană de Psihiatrie recomandând și altor legiuitori interzicerea ei pe motiv că ar fi ,dăunătoare și discriminatorie" $" 72$.

Democratul Brian Sims și-a susținut proiectul de interzicere a terapiei de conversie motivându-și propunerea prin faptul că aceasta ,poate fi dăunătoare pentru oricine, dar este deosebit de dăunătoare pentru tineri" ${ }^{\prime 3}$. Potrivit lui Joseph Nicolosi, deciziile diverselor organizații care se luptă să interzică terapia de conversie sau opinii precum cea a lui Brian Sims ,nu se bazează pe știinţă, ci depind de grupuri speciale de interes, de diverşi factori politici, de forțe economice, de relații publice" "74. În susținerea celor afirmate de Nicolosi, Jeffrey Satinover afirmă că ,întregul câmp de domenii a devenit într-atât de politizat încât, în prezent, nu există decât un singur punct de vedere corect care îți este permis să îl ai, fără a fi nevoit să plătești un preț profesional și academic ridicat" ${ }^{75}$. Nu doar interzicerea terapiei de conversie a fost o decizie influențată politic și ideologic, ci chiar un spectru larg de domenii de activitate

${ }^{70}$ PGN Staff, art. cit.

71 Bobby Allyn, Pennsylvania, Philly take stapes to ban 'conversion theraphy', January 19, 2017, disponibil la https://whyy.org/ articles/pennsylvaniaphilly-take-steps-to-ban-conversion-therapy/ (accesat la data de 17.07.2018).

${ }^{72}$ American Psychiatric Association, APA Reiterates Strong Opposition to Conversion Therapy, disponibil la https://www.psychiatry.org/ newsroom/news-releases/apa-reiterates-strong-opposition-to-conversiontherapy (accesat la data de 8. 07. 2020).

${ }^{73}$ Bobby ALLYN, art. cit. .

${ }^{74}$ Family Watch International, Understanding Same-Sex Attraction, disponibil la https://www.youtube.com/watch?v=jJhy zqdzpnM (accesat la data de 5.07.2018).

${ }^{75}$ Ibidem. 
inclusiv activitatea știinţifică ,sunt influențate acum de ideologie mai degrabă decât de cercetarea pură" 76 .

\section{Mărturii ale foștilor homosexuali și lesbiene}

Dovada cea mai evidentă a posibilității schimbării și a eficienței terapiei de conversie o reprezintă până la urmă vocea foștilor homosexuali (,ex-gay”), persoane care mărturisesc deschis că au avut în trecut atracții față de persoanele de același sex, au manifestat o orientare și un comportament homosexual, dar că prin intermediul diferitelor forme de terapie la care au apelat sau unii chiar fără a apela la terapie, au făcut trecerea spre heterosexualitate. În încheiere am să prezint mărturiile câtorva dintre aceste persoane.

Lansarea în dezbatere publică a proiectului de lege $A B$ 2943, care avea drept scop interzicerea terapiei de conversie, a stârnit în California o seamă de reacții. Printre acestea se numără și apariția unui filmuleț intitulat I'm a fraud ${ }^{77}$ (Sunt un impostor) în care sunt prezentate mărturiile unor foști homosexuali și lesbiene care au renunțat la homosexualitate, sau căsătorit, unii având chiar copii, și care dezaprobă proiectul deoarece, în caz că ar fi aprobat, acesta ar face din ei impostori (de aici și titlul filmulețului). Spre exemplu, Elisabeth Woning afirmă următoarele: „Am trăit ca lesbiană şi mi-a plăcut mult. Mi se părea că așa mă născusem. Nu L-am căutat pe Dumnezeu pentru a găsi o și mai mare eliberare sexuală. L-am căutat pe Dumnezeu pentru El Însuşi. Rezultatul a fost că, atunci când Lam găsit, am început să mă schimb. Și, în nu mai mult de un an, am început să mă simt atrasă de un bărbat, ceea ce, sincer vorbind, mi s-a părut șocant și puțin umilitor. Nu-mi venea să

${ }^{76}$ Dermot O'Callaghan, Peter May, Beyond Critique: The Misuse of Science by UK Professional Mental Health Bodies, 2nd ed. Hillsborough, Core Issues Trust, 2013, apud Christopher C. H. СоOK, art. cit. .

77 Church United, I'm a fraud, disponibil la https://www.facebook.com/ watch/?v=1749241568471897 (accesat la data de 20.07.2020). 
cred că eram eu însămi. Nu-mi venea să cred că așa ceva era posibil. Până la urmă, m-am căsătorit cu el și suntem împreună de 13 ani" "78. Există numeroase mărturii asemănătoare celei lui Elisabeth Woning care atestă faptul că homosexualitatea poate fi depășită și descriu în amănunt procesul tranziției la heterosexualitate ${ }^{79}$.

În SUA se organizează de mai mulți ani Marșul Libertății (Freedom March) ${ }^{80}$, la care participă persoane foste LGBT. Ei sunt o mărturie vie că, prin puterea Duhului Sfânt, eliberarea de păcatele sexuale și de rănile de tot felul este cu adevărat posibilă. Am amintit mai sus de Luis Javier Ruiz, unul din participanții la Marșul Libertății din Washington D.C. din 2019, pentru care părăsirea stilului de viață homosexual și îmbrățișarea heterosexualității reprezintă nu doar ,trecerea de la situația de persoană gay la situația de persoană hetero, ci de la situația de persoană pierdută la situația de persoană mântuită".

Unul din cei care au experimentat schimbarea și a avut parte de o tranziție satisfăcătoare spre heterosexualitate este și Michael Glatze, fost activist gay, fost redactor-șef al revistei Young Gay America și în același timp fondatorul acesteia. El spune că:

„eliberarea de influența unei mentalităţii homosexuale a fost cel mai eliberator, frumos și uimitor lucru pe care 1-am trăit vreodată. Dumnezeu a venit la mine când eram derutat și pierdut, singur, înfricoșat și răscolit. În timpul rugăciunii mia dat de înțeles că nu ar exista nimic față de ce ar trebui să

${ }^{78}$ Ibidem, apud Știri pentru Viață, Mărturiile unor foști homosexuali și lesbiene: „Sunt mai mult decât propria sexualitate”, disponibil la https://stiripentruviata.ro/marturiile-unor-fosti-homosexuali-si-lesbiene-suntmai-mult-decat-propria-sexualitate/ (accesat la data de 9.06.2018).

79 A se vedea: North Star International, Voice of Hope Project - Interview Highlights $_{2}$ disponibil la https://www.youtube.com/watch?v=tX18GwGxT1o \&list=PLcQ-4U_rJPaOgTb8KVxG7LW6UWijF486Q (accesat la 20.07.2020). Vezi și North Star, Voice(s) of Hope, disponibil la https://www.northstarlds.org/voices-of-hope (accesat la data de 20.07.2020).

${ }^{80}$ În anul 2019, Marșul Libertăţii a avut loc în mai multe state americane: 25 mai în Washington D.C., 23 iunie în St. Paul (Minnesota), 14 septembrie în Orlando. 
mă tem și că aș fi acasă. Doar o curățenie mică a casei mai era necesară. Homosexualitatea mi-a luat aproape 16 ani din viață... Ca unul dintre conducătorii pentru «drepturile homosexualilor», am avut de multe ori ocazia de a mă adresa unui auditoriu larg. Dacă aș putea retracta astăzi ceva din cele spuse atunci, aș face-o. Știu acum că homosexualitatea este concupiscență şi pornografie laolaltă. Nimeni nu mă va convinge de contrariu, indiferent de cât de abil îmi vorbește sau cât de tristă este povestea unui afectat. Pentru că am fost acolo. Cunosc adevărul" ${ }^{\prime 1}$.

\section{Concluzii}

Cercetarea științifică realizată până în prezent ne arată că în rândul populaţiei există o largă majoritate care de-a lungul vieții manifestă stabilitate în ceea ce privește identitatea, atracția şi orientarea sexuală, că doar o minoritate prezintă fluctuații, iar acestea sunt mai pronunțate în rândul persoanelor homosexuale.

Dintre persoanele care au urmat terapia de conversie, o parte s-au schimbat într-o oarecare măsură, dar nu s-au schimbat mult; alții - mai ales dintre cei foarte motivați - s-au schimbat mult; unii nu s-au schimbat deloc chiar dacă și-au dorit, iar alții - dintre cei care se considerau a fi homosexuali - nu s-au schimbat deloc, neavând niciun interes să o facă. Deși nu se schimbă toți cei ce urmează terapia de conversie, o parte dintre cei implicați înregistrează un anumit grad de progres, iar în cazul celor foarte motivați, schimbarea spre heterosexualitate este una semnificativă.

Atât unele studii realizate, cât și mărturiile celor care au depășit într-o oarecare măsură pornirile homosexuale, confirmă faptul că o abordare terapeutică religios-spirituală, axată pe cunoaşterea cuvântului lui Dumnezeu, pe rugăciune şi îndrumare spirituală, duce la nașterea din nou a omului la o

${ }^{81}$ Michael Glatze, Ich bin dort gewesen, ich kenne die Wahrheit, disponibil la http://www.hv-cv.de/23.html, apud Gabriele KuBY, op. cit., p. 263. 
viață spirituală care îl poate menține în comuniune cu Dumnezeu, departe de păcat ${ }^{82}$.

$\cos 80$

\section{Bibliografie}

1. AdLER, Sarah / LEVIN, Edmund, Some Gays Can Go Straight, Study Says, disponibil la https://abcnews.go.com/Health/Sex/ story? $\mathrm{id}=117465$ \&page $=1$ (accesat la data de 15.07.2020).

2. Allyn, Bobby, Pennsylvania, Philly take stapes to ban 'conversion theraphy', January 19, 2017, disponibil la https://whyy.org/ articles/pennsylvania-philly-take-steps-to-ban-conversion-therapy/ (accesat la data de 17.07.2018).

3. American Psychiatric Association, APA Reiterates Strong Opposition to Conversion Therapy, disponibil la https://www.psychiatry.org/ newsroom/news-releases/apa-reiterates -strong-opposition-to-conversion-therapy (accesat la data de 8.07.2020).

4. American Psychological Association (APA), Report of the American Psychological Association Task Force on Appropriate Therapeutic Responses to Sexual Orientation, Washington, D.C., 2009, disponibil la https://www.apa.org/ pi/lgbt/resources/ therapeuticresponse.pdf (accesat la data de 18.07.2020).

5. American Psychological Association, Resolution on Appropriate Afirmative Responses to Sexual Orientation Destress and Change Efforts, disponibil la https://www.apa.org/about/policy/sexualorientation (accesat la data de 8.07.2020).

6. AranA, Gabriel, My So-Called Ex-Gay Life. A deep look at the fringe movement that just lost its only shred of scientific support, disponibil la: https://prospect.org/ civil-rights/so-called-ex-gay-life/ (accesat la data de 17.07.2020);

82 Într-o viitoare prezentare, voi urmări o confruntare a datelor din actualul raport cu opiniile mai multor duhovnici ortodocși care s-au întâlnit în activitatea lor misionar-pastorală cu persoane homosexuale care au făcut unele eforturi de schimbare a orientării sexuale. 
7. Armelli, Jerry A. / Moose, Elton L. / Paulk, Anne / Phelan, James E., „A response to Spitzer's (2012) reassessment of his 2003 study of reparative therapy of homosexuality", în Archives of Sexual Behavior, Vol. 41, 6/2012, p. 1335-1336.

8. Church United, I'm a fraud, disponibil la https:// www.facebook.com/watch/? v=1749241568471897 (accesat la data de 20.07.2020).

9. CIUNGU, Ion, Iisus în centrul cunoașterii..., disponibil la https://doisautreiinnumele luiiisus. blogspot.com/2019/05/iisus-incentrul-cunoasterii-ii-poate.html (accesat la data de 25.05. 2019).

10. CoOK, Christopher C. H., „Science and theology in human sexuality", în Theology \& Sexuality, Vol. 24, 3/2018, p. 183-199.

11. DAvison, Gerald C., „Politics, ethics and therapy for homosexuality", în GONSIOREK, J., Homosexuality and psychotherapy, NY, Haworth Press), 1982, p. 89-96.

12. Diamond, Lisa M., „Sexual Fluidity in Male and Females”, în Current Sexual Health Reports, 8/2016, p. 249-256.

13. Family Watch International, Understanding Same-Sex Attraction, disponibil la https://www.youtube.com/watch?v=jJhyzqdzpnM (accesat la data de 5.07.2018).

14. GANNA, Andrea et alli, Large-scale GWAS reveals insights into the genetic architecture of same-sex sexual behavior, Science, 2019, Vol. 365, No. 6456, disponibil la https://geneticsexbehavior.info /wpcontent/uploads/2019/08/ganna 190830.pdf (accesat la data de 28.09.2019).

15. HALDEMAN, Douglas C., „The practice and ethics of sexual orientation conversion therapy", în Journal of Consulting and Clinical Psychology, Vol. 62, 2/1994, p. 221-227.

16. Jones, Stanton L., Ex-Gays? Part 1: Research Design, disponibil la https://www.youtube.com/watch? $\mathrm{v}=\mathrm{I} 10 \mathrm{jcafnqfc}$ (accesat la data de 7.07.2020).

17. Jones, Stanton L. / YARHOUSE, Mark A.,, „A Longitudinal Study of Attempted Religiously Mediated Sexual Orientation Change", în Journal of Sex and Marital Therapy, Vol 37, 5/2011, p. 404-427.

18. IDEM, „Ex Gays? An Extended Longitudinal Study of Attempted Religiously Mediated Change in Sexual Orientation", in Sexual Orientation and Faith Tradition Symposium, APA Convention, 2009, disponibil la https://www.wthrockmorton.com/wpcontent/uploads/2009/08/Jones-and-Yarhouse-Final.pdf (accesat la data de 18.07.2020). 
19. KATZ-Wise, Sabra L. / HydE, Janet S., „Sexual Fluidity and Related Attitudes and Beliefs among Young Adults with a SameGender Orientation", în Archives of Sexual Behavior, Vol. 44, 2015, p. 1459-1470.

20. KuBY, Gabriele, Revoluția sexuală globală. Distrugerea libertății în numele libertății, Iași, Edit. Sapientia, 2014.

21. LAMBERT, Jonathan, No 'gay gene': Massive study homes in on genetic basis of human sexuality, disponibil la https://www.nature. com/articles/d41586-019-02585-6 (accesat la data de 25.09.2019).

22. LAUMAnN, Edward O. / Gagnon, John N. / MichaEL, Robert T. / MichaEls, Stuart, The Social Organization of Sexuality. Sexual Practices in the United States, Chicago, Illinois, University of Chicago Press, 1994.

23. MANTA, Ilie Cristian, „Rolul eredității și al educației în apariția și dezvoltarea comportamentului homosexual", în Altarul Reîntregirii, 1/2019, p. 117-134.

24. MAYER, Lawrence S. / MCHUGH, Paul R., „Sexuality and Gender: Findings from the Biological, Psychological, and Social Sciences", în New Atlantis, 50/2016, p. 1-143.

25. MOCK, Steven E. / EIBACH, Richard P., „Stability and change in sexual orientation identity over a 10- year period in adulthood", în Archives of Sexual Behavior, Vol. 41, 3/2012, p. 641-648.

26. Music, Graham, Nurturing Natures. Attachment and Children's Emotional, Sociocultural and Brain Development, Second Edition, New York, Routledge, Taylor \& Francis Group, 2007.

27. NICOLOSI, Joseph, Cauzele și tratarea homosexualității masculine, disponibil la https://www.youtube.com/watch?v= pkuMlypiChQ (accesat la data de 5.07.2017).

28. North Star International, Voice of Hope Project - Interview Highlights, disponibil la https://www.youtube.com/watch?v=tX18 GwGxT1o\&list=PLcQ-4U_rJPaOgTb8 KVxG7LW6UWijF486Q (accesat la data de 20.07.2020).

29. North Star, Voice(s) of Hope, disponibil la https:// www.northstarlds.org/voices-of-hope (accesat la data de 20.07.2020).

30. O'Callaghan, Dermot, New Study: Effects of Therapy on Religious Men who have Unwanted Same-Sex Attraction, disponibil la https://www.core-issues.org/ leading-stories-and-research/newstudy-effects-of-therapy-on-religious-men-who-have-unwantedsame-sex-attraction (accesat la data de 20.10. 2019). 
31. O'Callaghan, Dermot / May, Peter, Beyond Critique: The Misuse of Science by UK Professional Mental Health Bodies, 2nd ed. Hillsborough, Core Issues Trust, 2013.

32. O'LEARY, Dale / BYRD, Dean / FITZGIBBONS, Richard P. / PHELAN, James E., The Same-Sex Attraction Factsheet, disponibil la http://www. familieslink.co.uk/download/sept07/same\%20sex\%20 alleged\%20fact\%20sheet. pdf (accesat la data de 28.04.2018).

33. OtT, Miles Q. / CoRLISs, Heather L. / WYPIJ, David / ROSARIO, Margaret / AUSTIN, S. Bryn, ,Stability and change in self-reported sexual orientation identity in young people: Application of mobility metrics", în Archives of Sexual Behavior, Vol. 40, 3/2011, p. 519-532.

34. PGN Staff, Sims To Introduce Bill To Ban Consersion Therapy, September 19, 2013, disponibil la https://epgn.com/2013/09/19/ 23644231-sims-to-introduce-bill-to-ban-conversion-therapy/ (accesat la data de 17.07.2018).

35. RosIK, Christopher H., „A research review of 'Parent-initiated sexual orientation change efforts with LGBT adolescents: implications for young adult mental health and adjustment' by Ryan et alli.", în Journal of Human Sexuality, Vol. 10, 2019, p. 79-83.

36. IDEM, „Perspectives from the Front Lines of Therapy Ban Conflicts: An Interview with Peter Sprigg and Greg Burt", în Journal of Human sexuality, Vol. 10, 2019, p. 66-73.

37. SAntero, Paul L. / Whitehead, Neil E. / Ballesteros, Dolores, „Effects of Therapy on Religious Men Who have Unwanted SameSex Attraction", în The Linacre Quarterly, 2018, p. 1-17.

38. SATIOVER, Jeffrey B., The „Trojan Couch": How the Mental Health Associations Misrepresent Science, disponibil la https://pdfs.semanticscholar.org/8ba2/ e0abf9e8d921bbb2447eab90 f8b47c52ab1b.pdf?_ga=2.77721748.1651372620.1567087942600799073.1567087942 (accesat la data de 14.07.2020).

39. SAVIN-WILLIAMS, Ritch C. / REAM, Geoffrey L., „Prevalence and stability of sexual orientation components during adolescence and young adulthood", în Archives of Sexual Behaviour, Vol. 36, 2007, p. 385-394.

40. Secretele Istoriei, Cazul David Reimer, un experiment psihologic care a șocat, disponibil la https://cultural.bzi.ro/cazul-david-reimerun-experiment-psihologic-care-a-socat-17401, (accesat la data de 8.11.2017). 
41. SHIDLO, Ariel / SCHROEDER, Michael, „Changing sexual orientation: A consumers' report", în Professional Psychology: Research and Practice, Vol. 33, 3/2002, p. 249-259.

42. SHOWALTER, Brandon, Ex-LGBT men, women to share stories of transformation at 2nd Freedom March in Washington, D.C., disponibil la https://www.christianpost.com/news/ex-lgbt-menwomen-to-share-stories-of-transformation-at-2nd-freedom-marchin-washington-dc.html (accesat la data de 25.05. 2019).

43. SPITZER, Robert L., „Can some gay men and lesbians change their sexual orientation? 200 participants reporting a change from homosexual to heterosexual orientation", in Archives of Sexual Behavior, Vol. 32, 5/2003, p. 403-417.

44. IDEM, „Spitzer reassesses his 2003 study of reparative therapy of homosexuality", in Archives of Sexual Behavior, Vol. 41, 4/2012, p. 757.

45. Știri pentru Viață, Mărturiile unor foști homosexuali şi lesbiene: „Sunt mai mult decât propria sexualitate”, disponibil la https://stiripentruviata.ro/marturiile-unor-fosti-homosexuali-silesbiene-sunt-mai-mult-decat-propria-sexualitate/ (accesat la data de 9.06.2018).

46. Thermos, Vasileios, „The Orthodox Church, Sexual Orientation, and Gender Identity: From Embarrassment to Vocation", în The Wheel, 13-14/2018, p. 83-90.

47. THROCKMORTON, Warren, The Jones and Yarhouse study: What does it mean?, disponibil la https://www.wthrockmorton.com/ 2011/10/27/ the-jones-and-yarhouse-study-what-does-it-mean/ (accesat la data de 18.07.2020).

48. WHITEHEAD, Neil, „Prenatal hormones are only a minor contributor to male brain structure in humans", in Journal of Human Sexuality, Vol. 6, 2014, p. 104-126.

49. IDEM, „Publication and Retraction of the Santero, Whitehead, Ballesteros (2018) Study: A First-Hand Account", în Journal of Human Sexuality, Vol. 10, 2019, p. 74-78.

50. WHITEHEAD, Neil / WHITEHEAD, Briar, Se poate schimba orientarea sexuală, disponibil la https://contracurentului.com/sepoate-schimba-orientarea-sexuala/ (accesat la data de 27.01.2018).

51. Whiteway, Eleonor / ALEXANDER, Denis R., „Understanding the causes of same-sex attraction", în Science \& Christian Belief, Vol. 27, 1/2015, p. 17-40. 
52. Williams, Thomas D., Ex-Gays Fight LGBT Power Play to Outlaw Conversation Therapy, disponibil la http://www.pravmir. $\mathrm{com} / \mathrm{williams-ex}$-gays-fight-lgbt-power-play-to-outlaw-conversion -therapy/ (accesat la data de 20.07.2020).

53. YARHOUSE, Mark A. / THROCKMORTON, Warren, „Ethical issues in attempts to ban reorientation therapies", in Psychotherapy: Theory Research/Practice/ Training, Vol. 39, 1/2002, p. 66-75. 